\title{
A Modern-Day Journey in Byron's Footsteps in Albania
}

\section{Ilda Erkoçi}

Luigj Gurakuqi University of Shkodër

\section{Doi:10.5901/ajis.2012.v2n4p97}

\begin{abstract}
:
Within a context of literary tourism, this paper starts with an overview of the Albanian motifs in world art and especially world literature to later more specifically focus on Byron and Albania. The poet's contribution to the literary discovery of Albania is highlighted. Tourist profile is built through an analysis of the impressions they have left mainly in the form of diaries. The paper also tries to briefly investigate the effect of the Byron craze on the potential travel behaviour of prospective tourists. In addition, expectations and place authenticity are also considered. The paper concludes that considering the tourist interest, the existing trail should be better developed and that the tourists' impressions offer a good feedback on the kind of development needed.
\end{abstract}

Key terms: Byron, Albania, Childe Harold, literature, tourism

\section{Introduction: Byron's Albania}

In the foreword to Shqipëria dhe shqiptarët në vepra të piktorëve të huaj (Albania and the Albanians in world art), Ismail Kadare wrote: "Although Albania was forgotten by states and rulers, European art did not forget it. Byron, Vivaldi, Delacroix and dozens of other famous artists continued their search for original themes in the events, sounds and colours of this land" (Hudhri 1990, p.8).

Foreign writings which deal with the Albanian theme appeared earlier than the first book in Albanian, Meshari (1555). According to literary critic Refik Kadija, such writings go back to antiquity where Illyria and Illyrians were mentioned not only in the historical works of Pliny and Plutarch, but also in the literary works of Plautus, Ovid, Virgil, Horace, and even Aeschylus. (p.248) The sources for the external literary production on Albania have been various. Some authors would resort on earlier writings, most important of which were the antiquity historical and literary sources; others would rely on the artistic representation of paintings. However, there were also those who would draw their raw material from direct contact with the country. Outstanding among them was the British poet George Byron (1788-1824, best known as Lord Byron) who has been credited with opening up Albania to the English public with his long poem Childe Harold's Pilgrimage (1812).

In 1809, Byron set off on a European tour. He eventually found himself in Albania, where he was very well received by Ali Pasha Tepelena, the so-called 'Lion of Janina'. His visit to Albania and favourable impressions of the country were recorded in 360 lines in the second canto of Childe Harold:

Land of Albania! Where Iskander rose,

Theme of the young, and beacon of the wise,

And he his namesake, whose oft-baffled foes

Shrunk from his deeds of chivalrous emprize;

Land of Albania! let me bend mine eyes

Oh thee, thou rugged Nurse of savage men!

The Cross descends, thy Minarets arise,

And the pale Crescent sparkles in the glen,

Through many cypress-grove within each city's ken

(Canto II, Stanza 38) 
Analysis of his Albanian theme is however, not the object of this paper as this has already been dealt with by several scholars, both Albanian (Skender Luarasi ${ }^{1}$, Kristo Frasheri², Refik Kadija, Afrim Karagjozi, etc) and foreign (Giuseppina Knorr ${ }^{3}$, Borst ${ }^{4}$, Guzzeta ${ }^{5}$, Gustav Meyer, ${ }^{6}$ Thomas Moore $^{7}$, Carl Treimer ${ }^{8}$, Wiener ${ }^{9}$, etc)

In addition to Childe Harold, Byron also mentioned Albania and the Albanians in a number of letters to his mother and his friend, historian and ethnographer John Cam Hobhouse. The latter had accompanied Byron in most of his journey to Albania and written a book on it. ${ }^{10}$ Furthermore, Byron is known to have left records (which he himself had translated) on a number of polyphonic Albanian songs (Karagjozi, 2010, p 36), so that those interested have one more reason to follow his footsteps.

Another interesting fact to mention is the impact that his verse has had on other artists, becoming thus a source of inspiration for subsequent works of art as well as travels in discovery of this 'exotic' country and its people: "Byron was the first great poet to visit Albania. ... He incited the curiosity of a number of foreign travellers, poets and artists on Albania and the Albanians."11 (Karagjozi, 2010, p.6) French painter Delacroix is said to have written in his diary when working on his Albanian-themed paintings: "To inflame myself, I recall Byron's verses" (qtd. in Hudhri, 1990, p. 75). Some works of art were made by famous painters to serve as illustrations for Childe Harold. Hudhri notes that Byron has been referred to in many books of art where his words were used as captions to the paintings. Byron's assessment of the Albanian costume as "the most beautiful in the world" (qtd. in Hudhri, 1990, p. 75) in one of the letters to his mother, has generated a number of paintings of the poet, the most famous of which is that by Thomas Philips exhibited in the National Portrait Gallery of London and considered one of the painter's finest works to this day.

His impact was both direct (namely, people set off following his footsteps) and indirect (that is, they produced art on Albania - mainly in the form of paintings and verse - simply inspired by his poem). In the first group, are prominent among others painters Eduard Lear, Henry Cock, and Louis Duprè and travellers Turner, Holland, Ticknor, Thomas Hughes, Joliffe and Edith Durham most of whom recorded their impressions in diaries which were often published. On the other hand, painters Camille Corote, Hugh Williams, Joseph Cartight, Eugene Delacroix, Alexander Decamps, Arry Selefter, William Heigert are among the artists who were inspired by his verse to produce art based on the Albanian theme. (Karagjozi, 2010, p. 333-354

Byron's Albanian theme is also known to have influenced his contemporary writer P. B. Shelley who dedicated 16 lines to the figure of Ali Pasha in his Hellas (1822). In addition, Byron's description of Albania is known to have inspired another of the best-known of his contemporaries, politician and writer Benjamin Disraeli, who, with this work in mind, set off for Albania in 1830 following Byron's tracks. He delighted in the landscape of Janine at the foot of "purple mountains of picturesque form" (qtd. in Elsie, 1993, p. 8) and Ali Pasha's palace: "The audience hall was the finest thing of the kind I had ever seen ... built by Ali Pasha purposely to receive the largest Goblin carpet that was ever made, which belonged to the chief chamber in Versailles, and was sold to him in the French Revolution" (Elsie, p. 9). Like Byron, Disraeli also liked Albanian costumes which he described in Contarini Fleming.

\footnotetext{
${ }^{I}$ SeeBajroni në Shqipëri. Nëntori, N.10. Tiranë 1959.

2 "Bajroni në Shqipëri dhe takimet e tij me Ali Pashën." Gazeta Mesuesi. Nr 19-20. Tirane 1963.

${ }^{3}$ Lord Byron e gli Albanesi. Catanzaro 1902

${ }^{4}$ Borst, A. William. Lord Byron's First Pilgrimage. London: New Heaven, 1948.

${ }^{5}$ Byron in Albania, Palermo 1978.

${ }^{6}$ Meyer, Gustav. Die albanischen Tanzlieder in Byrons "Childe Harold" Anglia 1893, XV

${ }^{7}$ Letters and Journals of Lord Byron with Notices of His Life. London 1847.

${ }^{8}$ Byron und die Albanologie

${ }^{9}$ Wiener, S.Harold. Byron and the East. Literary Sources of the Turkish Tales. London, 1939

${ }^{10}$ Hobhouse, John K. Letters from Albania

${ }^{11}$ My translation
} 


\section{A Byronian (re)discovery of modern Albania}

How many adventurous and literary curious people would be willing to follow Byron's footsteps nowadays, over 200 years after the appearance of Childe Harold? Is that possible? What is the profile of the modern byronian tourist to Albania? These were some of the initial questions which incited this paper. Additional questions include the kind of satisfaction they derive from their visit; how many literary pilgrims and more general tourists there are; and how relevant issues of authenticity and conservation are to this experience.

\section{Methodology}

The impressions left by tourists who have been in Byron's footsteps in Albania in the form of (mainly online) diaries, documentaries or even newspaper articles have been used as source for this paper. Their impressions have been analysed by the author with the purpose of building up the profile of the Byron tourist in this country and offering a few recommendations for developing a better-established trail.

\section{The trail}

Although some of the tourists have organized everything on their own, most of them arrived in Albania thanks to a package tour planned by Wild Frontiers Adventure Travel (a British company specialized in unbeaten tracks) in collaboration with the Albanian Auron Expeditions private company. Their guided tour on horseback or walking mirrors Byron's original itinerary to a considerable degree, though different routes are taken at times. The trail takes the tourists to some of the most beautiful landscapes of the region through Glina Village up to Tepelenë town, along the Vjosë River, exploring ancient monasteries, castles and visiting local villages.

\section{A profile of the Byronian tourist to Albania}

Adventured on a shore unknown,

Which all admire, but many dread to view ("CHP" 2.43.4).

Lands scarce noticed in historic tales ("CHP" 2.46.3-4).

Who are the tourists? What motivates their literary pilgrimage? Why does Byron still fascinate?

Unlike the elite class who would take the Grand Tour in Byron's time, modern tourists are armed only with their passion for literature. Whether they have come to Albania inspired by Byron's fascination with Ali Pasha, his exotic and often idyllic descriptions or his portrait in a wonderful Albanian costume, one thing is shared by them all: they want to experience at first-hand what Byron saw.

By reading their impressions which often appear in the vein of good old diaries, one realizes that it is mainly the reader-tourists' passion for the poet what inspires the journey. The visit is often seen as materialization of reading and adding a value to it. Some of the tourists have come because of their fascination with the writer - though some seem to be more attracted by his eccentric personality than as a man of letters; others because of his poem. Another group of tourists have been drawn to this particular literary place for some broader and deeper emotion than the specific writer or the story, such as nostalgia for the past as described in books or memories linked with childhood:

"Feels as if I was living in ancient Scotland" says British ambassador Fiona Mclleham (Serjani, "Dy ambasadore ne kerkim te Lordit Bajron", my translation)

Because one needs a starting point, I bought a travel guide, a second edition of 1988 . The cover displayed a Byzantine church which cheered me up. The place didn't look as mysterious as I had hoped [...] I was about 
to close the book, pretty disappointed, when my eyes caught glimpses of a chapter entitled "With Lord Byron in Albania." What? You had also been there? The letter you had sent your mother was published in full ...

When I read that letter, my old love for Byron came flooding back. I decided to travel with him, on horseback, making the same journey - even if it was two centuries later. I wanted to get to know not just Byron but Albania too... (cited in Bardhyli, my translation)

Tessa de Loo's In Byron's Footsteps recounts her expedition following the footsteps of the Lord Byron's tour of Albania in 1809. Enthralled by the image of Lord Byron as a teenage girl, she sets about exploring not only his physical journey, but attempts to understand his inner journey as well. So strong is her fascination with Byron, that she writes her book in letter form as Byron and Hobhouse had done over two centuries ago.

In addition to childhood memories and love for the author, Tessa was also curious to visit the country, which, for her was a mystery:

Once, from the Pantocrator in Crete I gazed towards the mountains that stood like the backs of patiently waiting elephants across the water from Corfu. But you had to walk back as that was the forbidden land. ... All the countries were open for visitors, but Albania. Everything was so mysterious, that my yearning to visit the country and learn what was behind those mountains only became more intensive. (cited in Bardhyli, my translation)

Another reason for going on literary tourism may be the same that we read fiction: the need to break off with daily routines in search of an exciting experience:

Contrasted to this all, life in a cold Dutch street had to end. I only wanted one thing: come with you. I would even go to Ali Pasha, as a shadow from the future, a traveller, a nostalgic ... (Bardhyli)

"Our trip to Albania truly was a pioneering trip. Each day brought the unexpected and therefore a true sense that we were indeed having a little adventure and all that it entailed", says Julie Beecher. (Wild Frontiers)

Often, the literary tourists seem to deliberately obscure the boundary between fiction and real life, attempting to become physically closer to the narrated world: "During this extraordinary journey, I feel like $\mathrm{Mr}$ Hobhouse, Lord Byron's friend and companion, who kept a diary of their journey in Southern Albania, from Ioannina to Tepelena in 1809" says traveller Minty Clinch. (Serjani, my translation)

Some tourists see the journey as an opportunity to compare and contrast the changes:

The minibus dropped me in the square at the entrance to Tepelena, in front of the statue of the town's most celebrated son, a reclining Ali Pasha, his beard flowing, pistols tucked into his belt. There is no palace now, but the fortress still stands. (blacksearomer)

Visitors seem to enjoy even a sense of doubt and wonder:

A rickety wooden bridge, slung between stone pillars, is the only link with the town for villagers on the other side. I stood at one end, half of the planks rotted away or missing, as many gaps as solid boards, and decided I did not need to cross. Halfway along the castle wall above the river is an entrance. Was this where Byron and Hobhouse arrived? (blacksearoamer, my italics)

A storm, similar to one that might have caught Byron himself, adds to the excitement and authenticity of the experience:

My first day in Zagori was washed out by a violent storm that must have been something like the one that overtook Byron. (blacksearoamer) 
In most cases, in addition to its literary values, the journey turns out to be a wonderful one per se thanks to the wonderful natural landscapes it offers:

Seen from the river, the long fortress wall stretches along the ridge above. It is a fine sight on a sunny morning. The turquoise river winds through the valley, the fortress on one side, hills rising on the other. (blacksearoamer).

In this pristine wilderness of mature forests and deep valleys, wildlife thrives. ... The silence was absolute ... and the uninterrupted forest that spread in all directions was truly stupendous. (Tenison, 2009, p. 160)

Looking back, the best of Albania was its sheer beauty, the remarkable vastness of the landscape and the extreme contrasts it threw at us all the time. The scale and sweep of massive, jagged mountain ranges and huge rocks are unlike anything I have seen anywhere in the world. Beetling chasms dropping to tiny fields and ribbons of pellucid water far, far below; the bucolic charm of the Breughelesque farmers, who belong to the Byronic landscape so perfectly; and the savage harmony of high cliffs and crags disappearing into cloud-girt summits way, way above, make the scenery as romantic as any early nineteenth-century painting. (Tenison, p. 191)

It also offers a way to get acquainted with traditions, taste typical food, and get to know new people, the 'heart-warming kindness of strangers', as Byron himself did:

The Albanian people are constantly surprising and occasionally contradictory: on first encounters, in glaring groups as we rode by, they could look the most farouche and intimidating rogues. Yet the moment we established rapport and scratched the surface of their innate and unbreakable carapace of hospitality, we quickly realised that they were the kindest and most wholeheartedly giving people to be found anywhere. (Tenison, p. 191)

"This hospitality of yours along with the taste of your meals are crucial elements in establishing the tourism industry" says Louella Tenison. ("Kalorës të rinj në gjurmë të vjetra", my translation)

When I reached the village square, dominated by a huge old tree, the storm got going again, unleashing the biggest hail stones I had ever seen, like good sized stones. I sheltered in a little taverna, which was promptly plunged into near darkness as the electricity went out. Having already eaten, I asked for a glass of local grappa, which was warming and pleasant. Even better, the lady brought me a little plate of delicious spitroasted pork, with some bread and onion, on the house. It seemed, for a moment, I was not just a customer, but, together with an elderly man in the corner, a guest who had sought refuge from the storm. (blacksearoamer)

This tendency might well be explained in scholar Herbert's scheme of exceptional qualities of the site (link with writer, association with setting for stories, association with affective values, nostalgia, memory, symbolism) and general ones (attractive setting, facilities or service, location on tourist itinerary). (p. 315)

Although not specifically stated in any of the tourists' impressions I analysed, I believe that Scanderbeg who is mentioned in Childe Harold "Land of Albania! where Iskander rose" ("CHP" 2.38.1) might well be a motif inciting tourism. I also believe (again this is not explicit in the impressions analysed) that some of them (mainly foreign visitors with some good background on Byron) might travel to discover why such a controversial figure like Byron is so famous and loved in Albania.

Prospective tourists could even set in search of "the exotic" as Byron himself did: "Byron casts a spell on his readers, entrancing them during Childe Harold's voyage into the land of the unknown." (Hyssen, 2003, p. 17) Such a journey might well be the one to be taken by those interested in the East and more specifically in "Orientalism" to look for truth in person. The fact that Byron described Albania as Other and as anything but easily accessible, only adds to the mystery, making the journey more luring and challenging: 
Byron's image as the Mad Albanian served many purposes, not the least of which is that it lent credence to his poetic writings on the East. ... Byron's poetry had oblique and blatant references to Albania and its people. Canto 2 of "Childe Harold's Pilgrimage" is full of awe-inspiring descriptions detailing the countryside and its inhabitants. ... Byron's lyrics and the notes accompanying this poem are his means of providing an Oriental adventure for his readers, positioning his protagonist (and himself) in an authoritative role with regard to the mysterious East. By creating an image of exoticism and "otherness," Byron shrouded his work in an aura of mystery and knowledge ... (Hyssen, p. 18-19)

By creating a sense of mystery Byron paints a picture of Albania as a location that must be searched out in order to be fully seen. (24-5) ... he wants to celebrate the foreignness of Albania and Albanians in order to draw interest from his readers. (Hyssen, p30)

Next, if you like horse-riding into the wild, that might be a further reason to go on Byron's trail whether you are interested in the writer and his work or not. That seems to have been the motivation for 14 professional and amateur British riders. Most important, being a relatively unbeaten track makes it pretty authentic. This is actually one of the strongest points of this trail, despite several difficulties encountered:

When night fell, they would read Lord Byron's poetry and excerpts from the diary of his friend, John Cam Hobhouse. When the sun rose, they would jump on their horses and ride the paths the British poet took in 1809 in southern Albania. (Hoxha)

We saw a side of Albania few are privileged to see and it touched us. We were lucky to do so before whatever changes lie ahead come to pass. (Tenison, p. 193)

The beauty of this magnificent wild countryside now came into sharp focus, as, looking down onto the valleys, one could almost picture Byron, Hobhouse and company trekking slowly and laboriously, through the dense woodlands below (Gregory)

The transforming effect that such an experience may have is also to be noted:

The source of inspiration for his poem, 'Childe Harold's Pilgrimage', the trail of Byron sets out de Loo's path, where she, in the midst of her gruelling pilgrimage, herself undergoes something of a transformation. (Vrij Nederland)

Some find the journey so inspiring as to end up writing travelogues like that of Tessa de Loo's in which she gives a detailed description of the journey to Albania as well as her personal reassessment of the life and works of Lord Byron.

Who are the literary tourists in Albania?

Although I opened this session stating that modern literary pilgrims no longer have to belong to the upper-class as in the old days, still it is to be noted that those following Byron's trail in Albania are most commonly well-educated tourists possessing the cultural background to understand and appreciate this kind of tourism. Tenison and his wife Louella, for example fall into a sophisticated category of tourists who had prior knowledge of the site and got well informed before setting off for their journey:

As I began researching Albania I became increasingly excited. I discovered that it is one of the wildest and most unspoilt places in Europe and that it has a rich and fascinating history as well as some of the greatest military and literary links with Britain. (Tenison, $p . x x$ ) As I dug deeper and deeper into anything Albanian, it was the literary connections that interested me most. Shakespeare set Twelfth Night in Illyria. (Tenison, $p$. xxiv)

I was hooked and began making plans to ride in the footsteps of these past travellers, artists, kings, poets, sportsmen and idealists. I wanted to see a side of Albania few foreigners had seen for many years .... . A 
whole new world of history, romance, adventure and wild landscapes was luring me to a country which I was beginning to realise deserved to be much better known. Albania! (Tenison, p. 24)

The above passage is significant in that the source of inspiration goes beyond Byron and his work; the poet's impact on others now becomes a source of motivation in its own right. The same is true, for most of those who took the trail, most of whom are foreign.

In terms of expectations, analysis of tourist accounts makes me believe that they are generally met. Disillusionment, however, is at times inevitable:

Çajld Harold

Kalanë e Tepelenës unë e pashë;

E shkretë ish, bedenat pa njeri,

As roje, as shtiza, as Ali Pashë,

Më nuk kumbon. Por heshtje. Qetësi.

Nuk pashë un' as zjarre sipër kullash,

As kuaj, as llambadha mbi xhami,

Por pashë tek libraria anës udhës

Si blinte "Çajld Haroldin" një fëmi (Ismail Kadare "Ëndërrime" 1957)

In most cases, dissatisfaction seems to result from uncleanliness and lack of care in heritage preservation:

There is no palace now, but the fortress still stands. Inside its walls are modern houses, higgledy-piggledy along scrappy litter-strewn streets, some of them derelict. ... But little has been done to show off Tepelena to its best advantage. However it looked when Byron visited, nothing has been preserved except for the stark fortress walls. Few tourists stop here, despite the name of the hotel. But the site is magnificent, the river lovely, the castle impressive. Tepelena could be something more. (blacksearoamer)

Finally, as far as authenticity is concerned, it can be said that although the trail is highly marked by authenticity, there are also socially constructed elements such as the plaque which commemorates Lord Byron's visit to Ali Pasha on the fortress walls in Tepelenë, but which do not spoil the experience, but rather, complement it.

\section{Limitations}

This case study analysed only the impressions of a few tourists, most of whom were not contacted in person. Despite this, the common points shared by most of them, make the findings reliable.

\section{Recommendations}

Even though Wild Frontier's and Tare's initiative is to be applauded, still, more should be done to further develop and improve the existing trail. Tourists' impressions, whether positive or negative must be taken into consideration by the heritage developers.

First and foremost, cleanliness. In addition to listing the assets of the experience, many of the tourists do not hesitate to mention lack of cleanliness as one of liabilities of their experience:

Inside its walls [the palace's] are modern houses, higgledy-piggledy along scrappy litter-strewn streets, some of them derelict ... . Was this where Byron and Hobhouse arrived? It is piled high with earth, rubble and rubbish now (blacksearoamer) 
Tare also acknowledges this problem:

The monuments and other cultural heritage of this area are in terribly poor condition, totally left up to fate. It's a shame for the government, the Ministry of Culture and the Municipality of Tepelenë, and the MPs who have left the legendary castle of Tepelenë in such a horrible state of neglect. Just think of these British tourists who having travelled for ten days in search of Byron's footsteps, and read every evening his romantic poetry, end their visit in a hole filled up with rubbish, which is still called Ali Pasha's Castle. (my translation)

Next, deficient infrastructure and the devastating impact of human activity are to mar the natural beauty and as such, the experience as well:

A rickety wooden bridge, slung between stone pillars, is the only link with the town for villagers on the other side. I stood at one end, half of the planks rotted away or missing, as many gaps as solid boards, and decided I did not need to cross. (blacksearoamer)

It would have been hard to demonstrate more clearly the contrast between Albania's natural beauty and the disastrous impact of man upon it. ... We intended to attempt a crossing of the wide, swirling waters of the Vjosë by a suspension bridge I had found on my recce and then to follow the far bank to a rendezvous at the next bridge with our crew, thus avoiding staying on a dangerous main road. Straight out of an Indiana Jones movie, the bridge looked on the verge of collapse. Several planks were missing, revealing vertigo-inducing drops to the torrent below, and everything swayed alarmingly as we led the horses over. (Tenison, p. 161) The way to our final destination, Erind, was indeed difficult. (p. 181)

They lead to some of the most dramatic and unspoilt coastal scenery left along either coast of the Adriatic but this is rapidly being threatened by the sort of development of which the Minister of Tourism would heartily approve. Perhaps the only benefit from Albania's isolation and poverty under communism was a coastline that was left untouched by mass tourism and its ugly trappings. Now much of it is dusty with urgent lorries and other heavy machinery building high-rise hotels and neon-lit restaurants. It will take time to destroy it all, but every effort seems to be under way to do so. (Tenison, p. 192)

As such, to further develop the Byron trail in Albania as a literary tourism site and manage it successfully, various tourist needs have to be catered for, including infrastructure, accommodation and routes. In the area, place should be commodified through a variety of related tourist attractions and specialised tourist services. This has already been done to a large extent by Wild Frontiers and Auron Expeditions and information can be obtained from their respective websites, but the local government must take its stand as well. Hyssen's observation that the relationship between Greece and Byron has been studied almost non-stop since Byron first visited that land (p. 62) gives a clue on the importance of the need for more promotion and advertisement. For instance, the trail could well be included in travel brochures and package holidays tourists might want to follow it because they are or plan to be in the area for their holidays. Byron had stated: "the Albanese struck me forcibly by their resemblance to the Highlanders of Scotland, in dress, figure, and manner of living." ("CHP" 878). This might be used to incite prospective tourists (especially from Scotland) looking for similarities and contrasts. Next, we know that Byron enjoyed the dancing and singing he witnessed. I believe that including such traditional folklore elements, would add the appeal. An annual festival in September with readings from Childe Harold commemorating the arrival of Lord Byron could be another interesting idea to enhance the experience. Road signs reading 'Byron was here' or other lines from Childe Harold throughout the trail would definitely make it more fascinating.

Most important, literary places must be protected and managed as heritage sites through their literary connection. The impression left by one of the visitors about the Greek side of the trail is noteworthy - he mentions that everything has been very well preserved in loannina, but can the same be said about Tepelenë? Unfortunately not: "But little has been done to show off Tepelena to its best advantage. ... Few tourists stop here, despite the name of the hotel. But the site is magnificent, the river lovely, the castle 
impressive. Tepelena could be something more." (blacksearoamer) Unlike the Greek side of the journey, the authorities here have done little to preserve values as is the case of the Ali Pasha's palace which is now inexistent or the castle which is poor condition. In addition, the view of the city itself with 'litter-strewn streets' is shameful.

I am totally aware of the costs, though not exactly how much, but I am not an economist, and it's not my job to calculate that - there are experts who can do that. Still, I believe that whatever cost is worthy considering the result, namely opening literary Albania to more tourists. The benefits will be multiple - cultural and literary as well as economic.

\section{Conclusions}

This paper focused on Byron's Childe Harold inspired tourism in Southern Albania. The choice of the case study was in part governed by the fact that it is the first and only literary trail existing in the country. It possesses both of what Herbert calls exceptional and general qualities as in addition to its literary values, the Byron trail in Albania also passes through a pleasant setting.

It is essential to explore further links between literary images and cultural meanings, values and communication. Any potential literary tourism site is a social construction that requires authentic development to attract visitors interested in experiencing the setting of books. Interest in literary tours and literary tourism appears evident, and places could be promoted owing to their association with well-known writers and their books. The linking of books with a destination could add value to a reader's experience of both. A literary place, such as Southern Albania as the setting for Byron's Childe Harold's Pilgrimage, can be regarded as a place that readers as consumers attach meaning to, and that draws tourists to the destination.

Literary heritage is increasingly seen as a means to pass heritage on to future generations through the medium of literature. Therefore, literary tourism can be deemed important, as it has positive socio-cultural and economic benefits, and may in addition result in positive educational (or other) benefits and worthwhile experiences for visitors (as potential readers).To further develop the Byron trail as a literary tourism site and manage it successfully, various tourist needs have to be provided for, including infrastructure, accommodation and routes.

In conclusion, I strongly believe that following Byron trail, other literary places could also be developed in the area or elsewhere in Albania by commodifying place through a variety of related tourist attractions and specialised tourist services. It is indispensible that such places be protected as heritage sites.

\section{References}

Bardhyli, A. (2006, October 17). Një franceze në gjurmët e Bajronit. Gazeta Shqip.

Blacksearoamer. (2012, November 11). Ioannina to Tepelena. Retrieved from blacksearoamer.livejournal.com/21730.html Byron, Lord. (1980). Childe Harold's Pilgrimage. Oxford: Clarendon Press.

Elsie, R. (1993), "Benjamin Disraeli and Scanderbeg. The novel 'The Rise of Iskander' (1833) as a contribution to Britain's literary discovery of Albania" in: Südost-Forschungen, Munich, 52 p. 25-52. Retrieved from http://www.elsie.de/pdf/articles/A1993Disraeli.pdf

Gregory, A. (2009). Albanian Byron Conference. Retrieved from irishbyronsociety.ie/pdfs/ albanianayronsocietyconference.pd

Herbert, D. (2001). Literary places, tourism and the heritage experience. Annals of Tourism Research, Vol. 28, No. 2, pp. 312-333

Hobhouse, Xh K. (2001). Letra nga Shqipëria. Tiranë: Toena.

Hoxha, R. (2011, Sept. 07). In the footsteps of Lord Byron 202 years later. Southeast Europe. Retrieved from http://www.southeast-europe.eu/index.php?id=1932

Hudhri, F. (1990). Shqipëria dhe shqiptarët në vepra të piktorëve të huaj. Tiranë: Shtëpia botuese 8 Nëntori.

Hyssen, S.S. (2003). Albie the Mad Albanian: The Cross-Cultural Influence between Byron and Albania. Master's Thesis. Retrieved from http://commons.emich.edu/theses

Kadare, I. Çajld Harold. Poezishqip. Retrieved from http://www.poezishqip.com/ismail-kadare/cajld-harold/ 
Kadija, Refik. (2003). "Tema dhe motive shqiptare në letërsinë angleze të traditës" në Studime shqiptare 12. Shkodër: Camaj-Pipa.

Kalorës të rinj në gjurmë të vjetra. (2007, September 6). Gazeta Shqip. Retrieved from

http://www.gazeta-shqip.com/kulture/3a7df3631924568b111a88551ea5336a.html

Karagjozi, A. (2010). Xhorxh Bajroni. Tiranë: Plejad.

Në gjurmët e Bajronit. (2012). Top Channel. Documentary

Serjani, E. (2012, June 8). Karvani i Bajronit ndalet ne Antigone. Gazeta Shqip.

--- $\quad$ (2010, December 1). Dy ambasadore në kërkim të Lord Bajronit. Gazeta Shqip.

Tare, A. (2011, July 12). Në gjurmët e Bajronit të panjohur. Revista Mapo.

Tenison, R.H. (2009). Land of Eagles: Riding through Europe's Forgotten Country. London: I.B.Tauris.

Albania Horse Trek: In the footsteps of Lord Byron. Wild Frontiers. Retrieved from http://www.wildfrontiers.co.uk/grouptours/albania-horse-trek-in-the-footsteps-of-lord-byron/2000285

Vrij Nederland. In Byron's Footsteps. Retrieved from http://www.thesusijnagency.com/TessaDeLoo.htm 